University of Wollongong

Research Online

Faculty of Business - Papers (Archive)

Faculty of Business and Law

$1-1-2017$

Accounting conservatism, bank lending and firm investment: Evidence from a quasi-experiment of China's stimulus package

Xiaofei Pan

University of Wollongong, xpan@uow.edu.au

Follow this and additional works at: https://ro.uow.edu.au/buspapers

Part of the Business Commons

Research Online is the open access institutional repository for the University of Wollongong. For further information contact the UOW Library: research-pubs@uow.edu.au 


\title{
Accounting conservatism, bank lending and firm investment: Evidence from a quasi-experiment of China's stimulus package
}

\author{
Abstract \\ Using a sample of China's listed firms between 2003 and 2014, this study finds that firms receive more \\ bank loans after the stimulus package which is less significant for firms with conservative accounting. In \\ addition, firms with conservative accounting exhibit higher investment efficiency, which becomes weaker \\ after the stimulus package which represents an exogenous shock to credit supply. Further analysis shows \\ that the abovementioned findings are more significant for non-SOEs, firms from less government- \\ favoured industries and regions, and firms with severe interest conflicts between debtholders and \\ shareholders. These results are robust for alternative specification and alternative measurements. \\ Overall, these findings suggest that the beneficial effects of accounting conservatism are subject to \\ institutional environments and government policies.

\section{Disciplines \\ Business}

\section{Publication Details} \\ Pan, X. (2017). Accounting conservatism, bank lending and firm investment: Evidence from a quasi- \\ experiment of China's stimulus package. Pacific-Basin Finance Journal, 44 64-79.
}




\title{
Accounting conservatism, bank lending and firm investment: Evidence from a quasi-experiment of China's stimulus package
}

\author{
Xiaofei Pan ${ }^{1}$ \\ School of Accounting, Economics and Finance, University of Wollongong, Australia
}

\begin{abstract}
:
Using a sample of China's listed firms between 2003 and 2014, this study finds that firms receive more bank loans after the stimulus package which is less significant for firms with conservative accounting. In addition, firms with conservative accounting exhibit higher investment efficiency, which becomes weaker after the stimulus package which represents an exogenous shock to credit supply. Further analysis shows that the abovementioned findings are more significant for non-SOEs, firms from less government-favoured industries and regions, and firms with severe interest conflicts between debtholders and shareholders. These results are robust for alternative specification and alternative measurements. Overall, these findings suggest that the beneficial effects of accounting conservatism are subject to institutional environments and government policies.
\end{abstract}

Key words: Accounting conservatism, bank lending, firm investment, stimulus package JEL: E5, G18, G34, M41

\footnotetext{
${ }^{1}$ Xiaofei Pan's email is xpan@uow.edu.au. Address: University of Wollongong, Northfield Avenue, Wollongong, NSW, Australia 2500.
} 


\section{Introduction}

The 2007-2008 global financial crisis reduced the liquidity of the banking sector, resulting in banking panic and the deterioration of investment environments, and thus reducing banks' incentives to lend and firms' incentives to invest (Ivashina and Scharfstein, 2010; Duchin et al., 2010). Recent studies document that conservative accounting can effectively ameliorate the negative consequences of the financial crisis and improve a firm's value (Francis et al., 2013; Balakrishnan et al., 2015). The benefits of accounting conservatism derive from the fact that it enforces the timely recognition of economic losses and provides informational advantages, such as reducing information asymmetry (Watts, 2003; LaFond and Roychowdhury, 2008), mitigating agency problems (Ahmend et al., 2002; Ahmed and Duellman, 2007; Garcia Lara et al., 2016) and lowering cost of capital (Zhang, 2008; Haw et al., 2014). These benefits are attributed to the monitoring role of accounting conservatism over self-dealing behaviours of shareholders and managers. This effective monitoring in turn improves firms' decision of capital allocation (Bushman and Smith, 2001; Ahmed and Duellman, 2011).

However, does this economic implication of conservative accounting still hold if the liquidity of the banking sector and investment environments are not adversely affected by the financial crisis? Specifically, in response to financial crisis, many countries have launched economic stimulus packages, aiming to restore economic growth. Some of them are implemented through increasing bank loan supply and encouraging firms to invest, such as the scenario in China. While a basic notion of how firms with conservative accounting respond to financial crisis is expected to hold in the US market that experiences capital freezing, it is unclear what happens to this mitigating role of accounting conservatism in economies that experience a credit expansion.

The purpose of this study is to examine the influence of accounting conservatism on bank lending incentives and firm investment efficiency in the context of China. This study is also aimed at examining this influence after the implementation of the stimulus package, which received broad attention from the media. These issues are important because bank loan supply and firm investment efficiency are key determinants of economic recovery and growth after the stimulus package. Examining these issues can gauge the financial implications of the accounting conservatism during the post-stimulus package period and advance our understanding of the beneficial effects of conservative accounting to both lenders and borrowers. 
In addition to the fact that China has experienced a credit expansion period following the implementation of the stimulus package, other important features to note when focusing on China are that most banks are controlled by the governments and most firms are bankdependent. These features of Chinese economy are well-suited for this study for several reasons. First, unlike the US market that has both private and public debt markets, the bond market in China is underdeveloped and bank loans are the main form of external finance, thus firms are more bank-dependent and their financing ability is more sensitive to exogenous shock of bank loan supply resulting from the stimulus package. This facilitates the examination of how accounting conservatism affects banks' lending incentives. Second, the prior documented beneficial effect of accounting conservatism on firm investment decisions holds in developed markets with strong legal enforcement (Ahmed and Duellman, 2011; Garcia Lara et al., 2016), and it is argued that the adoption of accounting conservatism and better investment decisions are both driven by a developed institutional environment. Nevertheless, the Chinese economy features an underdeveloped legal system and weak law enforcement, which facilitates this analysis to draw the meaningful inference of the accounting conservatism influence on firm investment efficiency. Third, the Chinese economy is under the control of the government with a fast growing private economy. Prior evidence suggests that government involvement in business discourages the adoption of conservative accounting (Bushman et al., 2006; Chen et al., 2010). In this sense, the variations of ownership structure in China provide a further robust setting to examine the role of accounting conservatism in the presence of government ownership. Fourth, in response to the global financial crisis, China launched the largest economic stimulus package at the end of 2008, which has contributed significantly to the recovery of the world's economy. This also provides a natural experiment to investigate the influence of accounting conservatism on bank lending incentives and firm investment efficiency. In addition, China is the largest emerging market which shares some common characteristics with other emerging markets, so the evidence from China can be generalized to other emerging markets.

To examine this issue, this study uses a difference-in-differences (DID) approach for estimation to compare the bank lending and firm investment efficiency before and after the implementation of the stimulus package as a function of firm accounting conservatism. However, a potential issue arises when firm accounting conservatism changes after the implementation of the stimulus package or is related to firm unobserved characteristics, so that firm accounting conservatism could be endogenously determined. To address this endogeneity issue, the specification is designed that firm accounting conservatism is 
measured one quarter prior to the implementation of the stimulus package, which is consistent with Duchin et al. (2010) and Garcia-Appendini and Montoriol-Garriga (2013). Using a large sample of quarterly data of all Chinese listed firms between 2003 and 2014, this study documents the following findings. First, after the implementation of the stimulus package, firms experience a larger increase in bank borrowing which is less significant for firms with conservative accounting. Second, firms with conservative accounting invest more efficiently which is less significant after the implementation of the stimulus package. Third, the above findings are more significant for non-SOEs (non-state owned enterprises), firms from less government favoured industries and regions, and firms with more severe interest conflicts between debtholders and shareholders/managers. The general results are robust for alternative specification and alternative measurements.

This study contributes existing literature in the following ways. First, existing studies document that accounting conservatism benefits borrowers in terms of lower financing costs (Zhang, 2008). This study complements this by documenting that firms with conservative accounting have access to more bank loans. In addition, prior literature argues that accounting conservatism is a corporate governance mechanism that decreases firm incentives to make negative NPV (net present value) investments and avoids riskier projects (Watts, 2003; Ball and Shivakumar, 2005; Ahmed and Duellman, 2011). Therefore, accounting conservatism can improve firm investment efficiency (Garcia Lara et al., 2016). This paper presents evidence of how accounting conservatism affects firm investment efficiency in an emerging market and thus, contributes additional evidence to the existing body of literature. Moreover, by focusing on the interest conflicts between debtholders and shareholders, this paper also examines the change of conservatism-investment efficiency relationship in response to the expansion of external finance.

More importantly, the beneficial effects of accounting conservatism have been documented to be more significant when firms experience capital contraction following the onset of financial crisis (Francis et al., 2013; Balakrishnan et al., 2015). The results of this study complement this line of research and document that beneficial effects of accounting conservatism are mitigated when firms experience capital expansion resulting from the stimulus package in response to financial crisis.

Second, Bushman et al. (2011) employ cross-country analysis and find that conservatism is associated with efficient investment. However, cross-country analysis could raise a few concerns. Specifically, there is a large variation of institutional environments across countries, including legal systems, taxation regimes, political economies and security laws. The 
observed variations of accounting conservatism and investment efficiency are likely to be the results of these institutional factors at the country level (Ball et al., 2008). Firms domiciled in the same country comply with similar accounting standards and regulations, and thus it is unclear whether conservative accounting can still be beneficial to firm-level investment decisions within a single country. With this in mind, this study applies single country analysis by focusing on the Chinese economy, which can overcome some of the criticisms of crosscountry studies, while holding constant of institutional factors that may be correlated with corporate investment decisions.

Finally, this study also contributes from a methodology perspective. In a related line of research, Ahmed and Duellman (2011) and Garcia Lara et al. (2016) focus on indirect measures of investment efficiency, such as firm future profitability. However, these indirect measures of investment efficiency are inferred and rely on ex post manifestation of investment decisions, and direct measure is scarce. In a departure from, but complementary to these studies, this paper directly and explicitly examines the issue that how accounting conservatism affects firm investment efficiency, measured by the sensitivity of investment expenditure to investment opportunities (Chen et al., 2011).

The remaining part of this study is organized as follows. Section 2 describes the background of the stimulus package in China and develops the main hypotheses. Section 3 presents the model and data. Section 4 shows the empirical results and discusses the implications. Section 5 shows the additional analysis and Section 6 concludes.

\section{Hypothesis development}

\subsection{Chinese stimulus package}

It is agreed that the Chinese economy has been hit heavily by the global financial crisis in 2008, and started to slowdown in the second half of 2008. In response to the global financial crisis, the Chinese government officially announced an economic stimulus package on the $5^{\text {th }}$ November 2008 , with the intention to restore domestic economic growth. This stimulus package was implemented from the fourth quarter of 2008 through to the end of 2010, and emphasized the expansion of the bank credit availability and increased investment spending by 4 trillion RMB, which accounts for $12.5 \%$ of total GDP in China in 2008. Of the total 4 trillion plan, the central government directly funded 1.18 trillion of the investment, which is $30 \%$ of the overall program, and the rest was funded by local governments. Meanwhile, a loose monetary policy was also emphasized by the central government to provide bank credit to support these investment activities (Naughton, 2009). In practice, there were 6 tranches of disbursement of the stimulus package, namely 108 billion in the fourth 
quarter of 2008, 130 billion, 70 billion, 80 billion and 223.8 billion respectively from the first to fourth quarters of 2009, and 992.7 billion in 2010. Altogether, the central government actually funded a stimulus package of 1.6 trillion, which is more than originally planned.

Meanwhile, local governments actively echoed the stimulus package announced by the central government, and contributed about $75 \%$ of fixed investments through budgetary expenditure at the regional level. In particular, by the end of 2008, 24 out of 31 administrative regions in China announced individual investment plan spending over various years. Those regions with larger investment plans are usually richer and have a more developed financial system, so that they usually have more bank credit available even during the normal times (Firth et al., 2009; Fan et al., 2011). For example, Yunnan and Hubei Provinces announced 3 trillion and 7 trillion RMB investment plans, respectively. ${ }^{2}$

When central government announced the stimulus package, detailed information of the investment capital distribution was also provided. According to the initial plan, $45 \%$ of the total investment would be awarded to transport and power infrastructure and $9.25 \%$ to rural village infrastructure. Later on in early 2009 , capital distribution was revised by reducing the investment in transport and power infrastructure from $45 \%$ to $37.5 \%$. The proportion of investments in other areas was increased slightly. When summarizing the investment capital distribution across the industries classified by the China Securities Regulatory Commission (CSRC), it is evident that capital distribution has been highly concentrated in the more favoured industries included in the Chinese Five Year Plans, such as construction, hightechnology and culture (Liu et al., 2016) ${ }^{3}$.

\subsection{Accounting conservatism and bank lending incentives}

The interest conflicts between shareholders and creditors provide incentives for shareholders to expropriate wealth from creditors, especially when firms approach financial distress. In order to protect their interests, creditors demand timely information about the value of the firms' assets. This becomes more significant in the event of liquidation due to stronger incentives of shareholders to delay the recognition of bad news for fear of losing control rights to firms' assets. Existing literature has documented systematic evidence of lenders' demands for conservative accounting and better terms of borrowing rewarded to conservative borrowers (Zhang, 2008; Haw et al., 2014; Nikolaev, 2010).

\footnotetext{
${ }^{2}$ Please see Liu et al. (2016) for detailed summary of the individual plans of each region, and the source can be obtained from the following links: http://www.china.com.cn/economic/txt/2008-11/24/content 16813059.htm, and http://www.csg.cn/epaper/html/2014-05/27/content_55643.htm.

${ }^{3}$ This classification is based on the information from the website at: http://www.china.com.cn/2009lianghui/2009-03/06/content_17387623.htm.
} 
Thus, many accounting-based debt covenants are required to restrain shareholders from opportunistic expropriations, which are only binding if the financial reporting system recognizes the deterioration of a firms' financial position. In this regard, conservative accounting can improve the effectiveness of these covenants, as it is the asymmetric timeliness of recognizing bad news as losses than good news as gains (Basu, 1997). In theory, accounting conservatism accelerates debt covenant violations and leads to more timely transfer of control rights from borrowers to lenders (Watts, 2003). Clearly, creditors will benefit from borrowers' adoption of conservative accounting with reduced credit risks, and are thus more likely to lend.

Due to either moral hazard or adverse selection concerns, firms still face capital rationing by creditors, and creditors are reluctant to lend when hit with the negative shock of capital supply which may result in unexpected increases of default risks of borrowers (Zhang, 2008; Balakrishnan et al., 2015). However, the stimulus package in China leads to an exogenous increase of bank loan supply and banks are required to rapidly ramp up their lending due to political pressures, regardless of firms' creditworthiness. Built on the above discussion, it is expected that the beneficial effect of conservative accounting becomes less pronounced, and firms with more conservative accounting experience a less increase in bank borrowing following the implementation of the stimulus package. Therefore, the first hypothesis to be tested is as follows:

H1: Accounting conservatism can increase firms' borrowing which becomes less significant following the implementation of the stimulus package.

\subsection{Accounting conservatism and firm investment efficiency}

Conservative accounting has a straightforward influence in rectifying investment inefficiency through improving financing capacity and mitigating agency conflicts. Due to these agency conflicts, shareholders are likely to undertake risky projects, or even those projects with negative net present value (NPV), at the expense of creditors (Klock et al., 2005; Chen et al., 2011), no matter whether their investment opportunities are promising or not, leading to severe inefficient investment.

Under conservative accounting, any losses from poorly performing investment will be timely recognized which is likely to violate debt covenants, so shareholders' ex ante incentives to undertake negative NPV projects are greatly reduced (Ahmed and Duellman, 2011; Garcia Lara et al., 2016). Therefore, accounting conservatism is an efficient mechanism to ensure positive NPV project investments and results in efficient investment. 
The above expectation, relating conservatism to investment efficiency, is also consistent with the prior argument that debt financing demands accounting conservatism (Watts, 2003a). As the fixed-income investors, lenders are usually concerned about their downside risks and face limited upside potentials, so they demand conservative accounting to timely recognize bad news which can also reduce default risks and their monitoring costs (Zhang, 2008). In this regard, conservative accounting is employed to protect lenders' interests and restrict managers/shareholders' wealth expropriation from lenders by undertaking projects with negative NPV. In addition, as accounting conservatism is an efficient contracting mechanism in mitigating agency problems (Ahmed et al., 2002; Watts, 2003; LaFond and Roychowdhury, 2008; Garcia Lara et al., 2016), and severe agency conflicts usually lead to investment inefficiency (Aivazian et al., 2005; Chen et al., 2011), accounting conservatism is consistently expected to enhance investment efficiency.

The influence of accounting conservatism is expected to be less significant following the stimulus package. As discussed above, during the post-stimulus package period, banks increase their lending substantially and these bank-dependent firms experience more capital availability. Thus, firm investment activities are boosted due to more sufficient capital to fund all profitable investment opportunities as well as suboptimal investments, resulting in a less efficient investment. Therefore, the second hypothesis to be tested is as follows:

H2: Accounting conservatism can increase firms' investment efficiency which is less significant following the onset of the implementation of the stimulus package.

\subsection{Ownership structure and accounting conservatism}

The above influences of accounting conservatism on bank lending and investment efficiency after the crisis are subject to ownership structure as state capitalism in China differentiates SOEs from non-SOEs (Chen et al., 2010). SOEs are ultimately controlled by the government which aims to achieve social and political objectives such as social stability, so they may not be permitted to be bankrupt and are able to negotiate with the government for ex ante policy favour such as lower financing costs and tax relief. In addition, the soft budget constraint towards SOEs also suggests that SOEs are more likely to receive government funding especially when they run into financial troubles. So SOEs would have a lower default risk. Moreover, the financial system in China is still controlled by the government, and the state owned banks are inclined to lend to SOEs due to political pressure without bearing financial consequence. The above discussion suggests that lenders are less concerned about the default risks of SOEs and thus less likely to demand conservative accounting (Chen et al., 2010). 
Moreover, Chen et al. (2011) argue that state capitalism will inevitably alter the objective function of SOEs to one preferred by politicians which leads to investment inefficiency. $E x$ ante, due to multiple objectives of the government, SOEs are not always undertaking profitable investment opportunities. Ex post, when investments fail to produce expected returns, it is difficult for SOEs to reduce or even terminate the investment due to potential conflicts with government policies.

Based on above discussions, it is logically expected that accounting conservatism has insignificant and limited influence on firm financing capacity and improving investment efficiency in SOEs, compared with non-SOEs.

In addition, the Chinese government announced an economic stimulus package which was exercised by government direct lending through the state-owned banking system, and most of the capital derived from this stimulus package was flowing to SOEs to help the whole economy to recover through increasing bank loan supply and boosting firm investment. In this sense, compared with non-SOEs, SOEs face less restrictions of bank lending and are thus less likely to deter their investment activities. In addition, these bank loans are considered as free resources rather than financial obligations, which further encourage SOEs to engage in suboptimal investments, no matter whether the investment opportunities are promising or not. Coupled with the insignificant influence of accounting conservatism in SOEs, it is expected that disappearing beneficial effects of accounting conservatism on obtaining more bank loans and improving investment efficiency after the stimulus package are less significant in SOEs. The next hypothesis to be tested is as follows:

H3: The influence of accounting conservatism on bank lending incentives and firm investment efficiency following the implementation of stimulus package becomes weaker in SOEs.

\section{Research design}

\subsection{Model specifications}

To test main hypotheses, a difference-in-differences (DID) approach is employed to compare the bank lending and firm investment efficiency before and after the implementation of the stimulus package as a function of firm accounting conservatism. One potential issue in the empirical design is that firms may change their accounting conservatism positions after the implementation of the stimulus package, in which case the accounting conservatism is endogenously determined. To address this potential issue, an identification strategy is applied in spirit of Duchin et al. (2010) and Garcia-Appendini and Montoriol-Garriga (2013) in which case that firm accounting conservatism is measured in the one quarter prior to the 
implementation of the stimulus package, specifically at the end of the last fiscal quarter ending prior to the $5^{\text {th }}$ November 2008. As the unobserved time-invariant heterogeneity at the firm-level may also create an endogeneity problem and bias the estimation results, firm fixed effects are thus included to control for this issue.

To test hypothesis H1, the following regression model is developed in the spirit of Zhang (2008) and $\mathrm{Li}(2015)$,

$$
\begin{aligned}
\text { Bankloan }_{i t} & =\alpha_{0}+\alpha_{1} \text { Stimulus }_{i t}+\alpha_{2} \text { C_Score }_{i t} * \text { Stimulus }_{i t}+\alpha_{3} \text { ROS }_{i t-1} \\
& +\alpha_{4} \text { Asset }_{i t}+\alpha_{5} \text { Sale }_{i t-1}+\alpha_{6} Q_{i t}+\alpha_{7} \text { Tangibility }_{i t}+\alpha_{8} \text { Board }_{i t} \\
& +\alpha_{9} \text { Indep }_{i t}+\alpha_{10} \text { LnGDP }_{i t}+\text { Firm }+\varepsilon_{i t}
\end{aligned}
$$

where Bankloan is the ratio of total bank loans to total assets. C_Score is the measure of accounting conservatism that will be explained later in Section 3.2. As discussed earlier, the value of accounting conservatism for each firm is measured in one quarter prior to the implementation of the stimulus package. Stimulus is a dummy variable, equals to 1 for firmquarter observations following the implementation of the stimulus package and 0 otherwise. As the stimulus package was implemented since the fourth quarter of 2008 , so accounting conservatism is measured in the third quarter of 2008 , and firm-quarter observations after this quarter are classified as post-stimulus package periods. $\alpha_{2}$ is used to test hypothesis $\mathrm{H} 1$, and according to the discussion of the hypothesis, $\alpha_{2}$ is predicted to be significantly negative.

To test hypothesis H2, this study employs the standard investment equation to explore the impacts of accounting conservatism on investment efficiency, following previous studies (Aivazian et al., 2005; Chen et al., 2011). Specifically, the model is expressed as follows:

$$
\begin{aligned}
\text { Investment }^{=} & \beta_{0}+\beta_{1} C_{-} \text {Score }_{i t} * Q_{i t-1}+\beta_{2} C_{-} \text {Score }_{i t} * Q_{i t-1} * \text { Stimulus }_{i t} \\
& +\beta_{3} C_{-} \text {Score }_{i t} * \text { Stimulus }_{i t}+\beta_{4} Q_{i t-1} * \text { Stimulus }_{i t}+\beta_{5} \text { Stimulus }_{i t}+\beta_{6} Q_{i t-1} \\
& +\beta_{7} \text { Lev }_{i t-1}+\beta_{8} \text { Asset }_{i t}+\beta_{9} \text { Sale }_{i t-1}+\beta_{10} \text { Tangibility }_{i t}+\beta_{11} \text { Cashflow }_{i t} \\
& +\beta_{12} \text { Board }_{i t}+\beta_{13} \text { Indep }_{i t}+\alpha_{14} \text { LnGDP }_{i t}+\text { Firm }_{i t}
\end{aligned}
$$

where Investment is firms' investment expenditure, measured as the ratio of capital expenditure (cash payments for fixed assets, intangible assets, and other long-term assets from the cash flow statements, less cash receipts from selling these assets) to total assets at the beginning of current quarter. This is consistent with Chen et al. (2011) and Xu et al. (2011). $Q$ is Tobin's $\mathrm{Q}$, defined as the ratio of firm market value to replacement value, which is the proxy for investment opportunities. Investment efficiency is reflected by the sensitivity of investment expenditure to investment opportunities, and $\beta_{2}$ is used to test hypothesis $\mathrm{H} 2$. According to the discussion of the hypothesis, $\beta_{2}$ is predicted to be significantly negative. 
Following Firth et al. (2009) and Zheng and Zhu (2013), a set of control variables, such as total assets, sales level and tangible assets, which have potential effect on bank loan ratio, are also included in equation (1). Following Chen et al. (2011) and Zheng and Zhu (2013), a set of control variables, such as Tobin's $Q$ and leverage, are also included in equation (2) which have a potential effect on firm investment expenditures. Moreover, as bank lending and firm investment are likely to be driven by macroeconomic conditions, GDP per capita at the provincial level is also included in both equations to control for the macroeconomic conditions ${ }^{4}$.

\subsection{Measuring accounting conservatism}

The tests require firm-specific accounting conservatism measures at the end of the third quarter of 2008 to be entered into both equations. Following Khan and Watts (2009), the C_Score is calculated and used as a primary measure for firm-specific accounting conservatism. This method has been used by Chen et al. (2013) in the context of China.

To calculate the C_Score, the following cross-sectional equation is estimated first for each quarter in the sample:

$$
\begin{aligned}
& E_{i t} / P_{i t-1}=\left(\lambda_{0}+\lambda_{1} \text { Size }_{i t}+\lambda_{2} \operatorname{Lev}_{i t}+\lambda_{3} M B_{i t}\right)+D R_{i t}\left(\kappa_{0}+\kappa_{1} \operatorname{Size}_{i t}+\kappa_{2} \operatorname{Lev}_{i t}+\kappa_{3} M B_{i t}\right) \\
& +R_{i t}\left(\mu_{0}+\mu_{1} \text { Size }_{i t}+\mu_{2} \operatorname{Lev}_{i t}+\mu_{3} M B_{i t}\right)+D R_{i t} * R_{i t}\left(v_{0}+v_{1} \operatorname{Size}_{i t}+v_{2} \operatorname{Lev}_{i t}+v_{3} M B_{i t}\right)+\varepsilon_{i t}
\end{aligned}
$$

where $E$ is earnings per share, $P$ is quarter-end share price, $R$ is quarterly buy-and-hold return, and $D R$ is a dummy variable equal to 1 if $R$ is negative and 0 otherwise. Size is the log of market value of equity, $L e v$ is leverage ratio, and $M B$ is market-to-book ratio. Then $C \_S c o r e$ for each firm-quarter is calculated as:

$$
C_{-} \text {Score }_{i t}=v_{0}+v_{1} \text { Size }_{i t}+v_{2} \text { Lev }_{i t}+v_{3} M B_{i t}
$$

As there is no commonly accepted proxy for accounting conservatism, this study also employs two alternative measures of firm-specific conservatism to check the robustness of the results. The first one is market-value based proxy (Con_Acc) and calculated as the bookto-market ratio multiplied by negative one, following Beaver and Ryan (2000). The second is accrual-based proxy (Con_Mar) and calculated as the income before extra-ordinary items, less cash flows from operations, plus depreciation expense deflated by average total assets at the beginning of current quarter, and averaged over a 3 -quarter period centred on quarter $t$, following Givoly and Hayn (2000). These two proxies have been used by Ahmed and Duellman (2007). The following part reports the empirical results using C_Score as the proxy

\footnotetext{
${ }^{4}$ Thanks the reviewer for this suggestion.
} 
for accounting conservatism and the results using alternative proxies are available on request. Definitions of all variables used in this study are listed in the Appendix.

\section{Empirical results}

\subsection{Summary statistics}

The sample of this study includes quarterly data of all Chinese listed firms on both Shanghai and Shenzhen stock exchanges between 2003 and 2014. Following the common procedure, the final sample for empirical analysis is obtained as follows. Specifically, firmquarter observations flagged with $\mathrm{ST}$ or $* \mathrm{ST}^{5}$, from financial industry or with missing information are excluded, and the final sample includes 62,700 firm-quarter observations.

All relevant data are obtained from the Chinese Securities Market and Accounting Research (CSMAR) database. In particular, the stock price and stock return are gathered from the Stock Market Trading database. Financial and governance information is gathered from the Financial Statement database and Listed Firm Governance database. To eliminate the outlier effects, all the continuous variables are winsorized at the $1 \%$ level. Table 1 shows the summary statistics of all variables. The summary shows that the mean (median) of the bank loans and investment expenditure are $23.99 \%$ (23.09\%) and $1.70 \%(0.91 \%)$, which are quite similar to those reported by Zheng and Zhu (2013) and Xu et al. (2011). C_Score has a mean of 0.235 and median of 0.214 as of the third quarter of 2008, which are broadly comparable to those reported by Chen et al. (2013). The summary statistics of the other two proxies for accounting conservatism are also consistent with existing studies (Ahmed and Duellman, 2007).

\section{[Insert Table 1 here]}

Before the multivariate analysis, this study first conducts some univariate tests to compare the differences in bank lending and firm investment between firms with more and less conservative accounting, before and after the implementation of the stimulus package. To do so, sample firms are divided into two groups based on the median values of the $C$ _Score in the third quarter of 2008, and those firms with higher values of the C_Score are grouped as more conservative accounting and others are grouped as less conservative accounting. The comparison results are reported in Table 2. In order to accommodate both bank lending and firm investment in the same table, bank loan ratios are reported in the table and investment expenditures are reported in the brackets. Consistent with the hypotheses, the comparisons for

\footnotetext{
${ }^{5}$ ST stands for Special Treatment and refers to the listed firms that have already had negative net profits for two consecutive years. $*$ ST refers to the listed firms that have already had negative net profits for 3 consecutive years and thus have the probability of being delisted from the stock exchanges.
} 
the full sample, SOE subsample and non-SOE subsample are reported separately in Panels A, B and C. First, as can be seen from Panel A of the table, more conservative firms are likely to receive more bank loans before the implementation of the stimulus package ( $\mathrm{t}$-value of the difference is 4.36), while this effect becomes weaker after the stimulus package (t-value of the difference is 1.99). Difference-in-difference test shows this change is statistically significant (t-value between before and after is 2.27). These results are consistent with the main hypothesis that conservative accounting is beneficial for firms while this beneficial effect becomes weaker after the expansion of bank credit. Panel B shows the comparisons for SOEs and it is apparent that conservative accounting is not necessarily a factor in obtaining external finance and firm investment in SOEs, supporting the hypothesis and the argument by Chen et al. (2010). Panel C shows the comparisons for non-SOEs which is similar to the comparisons for the full sample.

\section{[Insert Table 2 here]}

\subsection{Accounting conservatism and bank lending incentives}

Table 3 presents the results of testing for $\mathrm{H} 1$, the influence of accounting conservatism on bank lending incentives before and after the implementation of the stimulus package. Column 1 presents the results of the baseline equation and column 2 includes an interaction term of C_Score*Stimulus. In column 1, it is observed that the estimated coefficient of Stimulus is positive and statistically significant at the $1 \%$ level. This result suggests that when hit by the financial crisis, the stimulus package can rectify the liquidity of the banking sector, and firms experienced an increase in their bank borrowing. Specifically, the estimated coefficient of positive 0.037 suggests that the quarterly bank loan ratio by average firms increased by 0.037 percentage points following the stimulus package, an increase of $15.42 \%$ relative to an unconditional mean of $23.99 \%$ per quarter.

Column 2 shows that the estimated coefficient of C_Score*Stimulus is negative and significant at the 5\% level, suggesting that the significant increase in bank borrowing after the implementation of the stimulus package becomes weaker for firms with more conservative accounting. The estimated coefficient of negative 0.038 indicates that after the stimulus package, the quarterly bank loan ratio increased by 0.031 percentage points for firms with more conservative accounting, which is significantly lower than the increase of 0.069 percentage point by firms with less conservative accounting. In addition, control variables exhibit expected signs consistent with prior studies (Zheng and Zhu, 2013). Overall, the results in Table 3 are consistent with $\mathrm{H} 1$ that firms with more conservative accounting experience a less increase in bank borrowing following the implementation of the stimulus 
package than firms with aggressive accounting. In other words, bank lending becomes less responsive to accounting conservatism following the positive shock to the capital market in China.

\section{[Insert Table 3 here]}

\subsection{Accounting conservatism and firm investment efficiency}

Table 4 reports the results for testing $\mathrm{H} 2$, the influence of accounting conservatism on firm investment efficiency before and after the implementation of the stimulus package. Column 1 presents the results of the baseline regression, and columns 2 and 3 further include interaction terms. Across three specifications, Stimulus shows positive and significant coefficients, suggesting that firms experienced a sharp increase in investment after the implementation of the stimulus package.

The interaction terms from columns 2 and 3 are key results. In column 2, the coefficient of $C_{-} S \operatorname{Score}{ }^{*} Q$ is positive and significant at the $5 \%$ level, which is partially consistent with hypothesis H2. This result shows that investment expenditures are significantly more sensitive to investment opportunities for firms with more conservative reporting, indicating that more conservative firms are more efficient in their investments. In column 3 , the estimated coefficient of $C_{-}$Score $* Q *$ Stimulus is negative and significant at the $1 \%$ level, suggesting that the positive effect of accounting conservatism on firm investment efficiency becomes weaker after the stimulus package when the government encourages investment activities. Overall, these results are fully consistent with $\mathrm{H} 2$ that the beneficial effect of conservative accounting is mitigated by expansion of monetary policy, indicating that firm financial reporting is subject to the institutional environment and monetary policy. Again, in relation to control variables, the signs and magnitudes are expected and consistent with those reported in prior studies (Firth et al., 2008; Chen et al., 2011).

\section{[Insert Table 4 here]}

These empirical results face a potential issue of reverse causality. Though it is argued that the implementation of the stimulus package is an exogenous shock in response to the financial crisis, it could also be the case that the implementation of the stimulus package is exercised in response to the declining of bank borrowing and firm investment resulting from the financial crisis ${ }^{6}$. To address this reverse causality issue, the dynamic effects of the implementation of the stimulus package are investigated, using a method which is similar to

\footnotetext{
${ }^{6}$ Thanks the reviewer for this test.
} 
Bertrand and Mullainathan (2003). Empirically, the Stimulus dummy variable is replaced by four dummy variables: Before $e_{t-1}$ is a dummy variable equal to 1 for observations one quarter preceding the implementation of the stimulus package. Current is a dummy variable equal to 1 for observations in the quarter when the stimulus package is implemented. After $t_{t+1}$ is a dummy variable equal to 1 for observations one quarter after the implementation of the stimulus package. After $t_{t+2}$ is a dummy variable equal to 1 for observations two quarters or more after the implementation of the stimulus package. The variable Before $_{t-1}$ allows for the exploration of the reverse causality of any effect of bank lending and firm investment efficiency exists before the implementation of the stimulus package. The results reported in Table 5 show that the estimated coefficients of Before $t_{t-1}$ and its interaction terms are statistically insignificant, suggesting that such an effect is not found prior to the implementation of the stimulus package.

\section{[Insert Table 5 here]}

\section{Additional evidence}

\subsection{Ownership structure and accounting conservatism}

Table 6 lists the results for testing hypothesis H3, concerning the different influences of accounting conservatism between SOEs and non-SOEs. Empirically, a firm is identified as SOE or non-SOE as of the third quarter of 2008, and both equations (1) and (2) are estimated for both SOE and non-SOE subsamples separately, and the results of key variables are reported in each column of Table 6.

Again, interaction terms are the key interests. In Panel A for bank lending regression, the estimated coefficient of $C_{-}$Score $*$ Stimulus is -0.073 for non-SOEs which is significant at the $1 \%$ level (t-value is -2.93 ), and -0.024 for SOEs which is significant at the $5 \%$ level (t-value is -1.97). This result suggests that the beneficial effect of conservative accounting on obtaining more bank loans becomes mitigated after the stimulus package, which is more significant for non-SOEs, reflected by the larger absolute value of the coefficient for the nonSOEs. In Panel $B$ for firm investment regression, the estimated coefficient of C_Score ${ }^{*} Q *$ Stimulus is -0.056 for non-SOEs which is significant at the $1 \%$ level (t-value is -2.78 ), and -0.018 for SOEs which is insignificant ( $t$-value is -0.60$)$. This result suggests that the enhancing effect of accounting conservatism on firm investment efficiency becomes weaker after the stimulus package, which is significant for non-SOEs, reflected by the larger absolute value of the coefficient for the non-SOEs. To formally test whether the influence of accounting conservatism on bank lending incentives and firm investment efficiency are 
significantly different between SOEs and non-SOEs, Chow tests are conducted. In both Panels, Chow tests are 5.66 and 7.33, and are significant at both 5\% and $1 \%$ level, which empirically validate the significantly different influences of accounting conservatism between SOEs and non-SOEs. These results are consistent with hypothesis H3, and also corroborate the findings by Chen et al. (2010) that SOEs are less likely to adopt conservative accounting standards in China.

\section{[Insert Table 6 here]}

\subsection{Industrial and regional variations}

The Chinese central government launched the economic stimulus package in response to the financial crisis to increase the bank loan supply, and its influence is expected to be different across industries and regions. As summarized in section 2.1, the composition of investments had been directed toward specific industries that would boost consumption or have a direct impact on people's livelihood, such as transport and power infrastructure (railways, roads, airports and the electricity grid), rural village infrastructure, environment investment, affordable housing, technological innovation and education. Moreover, many local governments also infused various capital levels to their own provinces. Thus, there are large variations of capital injection and expansion across industries and regions. This section aims to explore whether the influences of accounting conservatism documented above vary across industries and regions. To do so, the full sample is divided into more and less favoured industries and regions. Specifically, more favoured industries include those industries mentioned by the stimulus package, including Construction, Technology, Culture and Conglomerate. More favoured regions include those provinces whose infused capital level is above the median value. Similar to the measurement of the firm accounting conservatism discussed in section 3.1, the identification of favoured industries and regions are also conducted in the one quarter prior to the implementation of the stimulus package. Empirically, both equations (1) and (2) are estimated for both industry and region groups and the results are reported in Tables 7 and 8.

The same as previous tables, the interaction terms C_Score ${ }^{*}$ Stimulus and C_Score ${ }^{*} Q *$ Stimulus are the key results from both Panel A and Panel B. Referring to both Tables 7 and 8 , it is observed that the estimated coefficients of these two interaction terms are more significant for firms from less favoured industries and less favoured regions. Again, Chow tests are conducted to test the significance of the different influences of conservative accounting between both subsamples. Overall, the partitions of industries and regions provide 
further evidence to explore the causal effect of accounting conservatism on bank lending incentives and firm investment decisions, and the general results are consistent with the main arguments that the beneficial effect of accounting conservatism becomes less pronounced when facing positive shock to the capital market.

However, these results seem to be counterintuitive that firms from less favoured industries and less favoured regions receive less bank credit, so that these firms should be less affected by the stimulus package. Actually, the explanations of these results follow the same rationale which is used to explain the comparisons between SOEs and non-SOEs, and it is argued that accounting conservatism matters more in firms from less favoured industries and less favoured regions. On the one hand, these favoured industries are actually included by the industries favoured by the Chinese Five Year Plans. In China, every five years the Chinese government announces a Five Year Plan identifying some specific industries that will be more supported or favoured by government policy. Though the favoured industries of each Five Year Plan vary to some extent, the industries favoured by the stimulus package are all included in these plans. On the other hand, these favoured regions are more developed regions and have more developed financial systems and more bank credit available (Firth et al., 2009; Fan et al., 2011). These arguments indicate that firms from favoured industries and favoured regions can receive more bank credit and the influence of accounting conservatism on bank lending and investment efficiency is expected to be less significant in these firms, compared with firms from less favoured industries and less favoured regions. Moreover, other firms still face a substantial expansion of bank credit after the implementation of stimulus package. Therefore, the influence of accounting conservatism could be significantly beneficial in these firms from less favoured industries and regions before the implementation of the stimulus package and this beneficial effect becomes weaker after the implementation of the stimulus package. In addition, the unreported univariate test shows that the average bank loan ratio and firm investment expenditures are both significantly higher for firms from the favoured industries and favoured regions before and after the implementation of the stimulus package, but the magnitudes of the increases of bank loans and investments are significantly higher for firms from less favoured industries and less favoured regions.

[Insert Table 7 here]

[Insert Table 8 here]

\subsection{Accounting conservatism and conflicts of interest}


It has been argued in the hypothesis that conservative accounting is required by the debtholders, so that conservative accounting is effective in mitigating the conflict of interest between debtholders and shareholders/managers and protecting the interests of debtholders. Then, it is expected that the beneficial effect of conservative accounting should be stronger in firms where the conflict of interest between debtholders and shareholders/managers is more severe and debtholders' interests are at risk $^{7}$. For example, when firms face the potential of financial distress, conflict of interests between debtholders and shareholders/managers becomes more severe as shareholders/managers may undertake riskier behaviours to expropriate debtholders which may then reduce the debtholders' claims. Moreover, as documented by both Boubakri and Ghouma (2010) and Lin et al. (2011), the deviation between the control rights and cash flow rights of the controlling shareholders leads to expropriation incentives and increases the credit risks concerned by debtholders and amplifies the agency problem between shareholders and debtholders. From this perspective, this section conducts some additional analysis to formally test this prediction. Empirically, consistent with the previous subsample regressions, the full sample is divided into two groups based on two partitioning variables. One is the Z-score, which is the proxy for the magnitude of financial distress potential, consistent with Altman (1968). The other one is the controlownership wedge, consistent with Boubakri and Ghouma (2010) and Lin et al. (2011). Empirically, both Z-score and control-ownership wedge are measured as of the third quarter of 2008 in this analysis. Those firms with larger Z-scores than the industry median level are grouped as less financial distress and other firms are grouped as more financial distress. Firms are also divided into two groups according to whether there is a control-ownership wedge. Then, both equations (1) and (2) are estimated to each subsample and the results are reported in Tables 9 and 10.

The same as previous tables, the interaction terms with Stimulus in both tables are of interest. As can be seen from Panel A of Table 9, the estimated coefficient of C_Score*Stimulus is -0.062 for firms with more financial distress which is significant at the $1 \%$ level ( $\mathrm{t}$-value is -2.78 ), and -0.013 for firms with less financial distress which is insignificant. The Chow test also confirms the significant difference in the influence of conservative accounting on bank lending between these two groups after the implementation of the stimulus package. The results in Panel B of Table 9 also show that the disappearing effect of conservative accounting after the implementation of the stimulus package is more significant

\footnotetext{
${ }^{7}$ Thanks the reviewer for this test.
} 
for firms with more financial distress. The results in Table 10 show a similar pattern to those in Table 9. These results provide empirical support to the main argument that conservative accounting provides benefits for firms through mitigating the conflict of interests between debtholders and shareholders/managers.

\section{[Insert Table 9 here]}

\section{[Insert Table 10 here]}

\subsection{Accounting conservatism and future profitability}

During the normal period, accounting conservatism is expected to be beneficial in terms of more bank borrowing and more efficient investments. Recent studies argue that efficient investments are more likely to lead to higher future cash flows, thus firms with more conservative accounting should have higher future profitability (Ahmed and Duellman, 2011; Garcia Lara et al., 2016). Following this line of research, it is expected that the positive relationship between accounting conservatism and future profitability becomes weaker after the stimulus package when the beneficial effect of accounting conservatism is mitigated. Consistent with Ahmed and Duellman (2011), the ratio of operating cash flows to total sales (Cashflow) in quarter $t+3$ is applied as the proxy for future profitability. In addition, return on assets (ROA) is also applied as an alternative proxy that has been used to measure profitability extensively.

Empirically, these two profitability proxies are regressed against key variables and a set of control variables, and the results are reported in Table 11. As can be seen from both specifications, the estimated coefficients of C_Score*Stimulus are negative and statistically significant. These results suggest that firms with conservative accounting exhibit a higher future profitability, while this positive association becomes weaker after the stimulus package. The general results are consistent with main arguments and support the hypotheses.

\section{[Insert Table 11 here]}

\section{Conclusion}

Whether and how financial reporting affects the real economy is of great interest to both academics and policymakers. This study contributes to this area of academic work by providing evidence on the role of financial reporting in affecting bank lending incentives and firm investment efficiency, using the Chinese government's stimulus package as a quasiexperiment. Specifically, this stimulus package represents a positive and exogenous shock to credit supply which results in credit expansion. This is in contrast to the situation in the US, where financial crisis results in a loss of liquidity in the banking system and credit contraction (Ivashina and Scharfstein, 2010). In addition, the stimulus package in China also 
encourages investment activities. Given these two distinct features following the implementation of the stimulus package, the influence of accounting conservatism is expected to exhibit different patterns from those reported in the US.

Using a large sample of China's listed firms between 2003 and 2014, this study finds that firms bank borrowing increases significantly after the stimulus package which is less significant for firms with conservative accounting. This study also finds that these firms make more efficient investment, which becomes less efficient after the stimulus package. Further analysis document that the above findings are less significant for firms with sufficient external financing, namely SOEs and firms from government favoured industries and regions. The above findings are more significant for firms with more severe interest conflicts between debtholders and shareholders. These results are robust for alternative specification and alternative measurements for accounting conservatism.

Existing studies have documented the beneficial effects of accounting conservatism for both borrowers and lenders, which is more pronounced when facing capital contraction (Zhang, 2008; Francis et al., 2013; Balakrishnan et al., 2015). However, this study offers additional evidence on the role of accounting conservatism using a counterexample of capital expansion in China, which presents a complementary perspective to existing literature. The main findings demonstrate that the influence of financial reporting becomes less pronounced when firms are likely to be favourably treated in terms of external financing when lenders are less likely to demand for conservative accounting. This study reveals important implications for policymakers in emerging markets. First, to restore economic growth in response to financial crisis, governments should increase their ability to create externalities and provide more profitable investment opportunities, while reducing government intervention in business through government-oriented policies. Second, the role of accounting conservatism should be emphasized, especially during the post-crisis period, to prevent firms from engaging in aggressive and risk-taking behaviours which may have long-term inefficient effects. More importantly, as the key component of the whole economy, the corporate sector should take the main responsibility for contributing to economy recovery instead of relying on government policies. In this institutional environment, the allocation of resources and corporate investment are of more efficiency, which is beneficial to economy recovery after the financial crisis at the country level. 


\section{Reference:}

Ahmed, A., Hillings, B., Morton, R., Stanford, M., 2002. The role of accounting conservatism in mitigating bondholder - shareholder conflicts over dividend policy in reducing debt costs. The Accounting Review 77: 867-890.

Ahmed, A., Duellman, S., 2007. Accounting conservatism and Board of Director characteristics: an empirical analysis. Journal of Accounting and Economics 43: 411-437.

Ahmed, A., Duellman, S., 2011. Evidence on the role of accounting conservatism in monitoring managers' investment decisions. Accounting and Finance 51, 609-633.

Aivazian, V., Ge, Y., Qiu, J., 2005. The impact of leverage on firm investment: Canadian evidence. Journal of Corporate Finance 11, 277-291.

Altman, E., 1968. Financial ratios, discriminant analysis and the prediction of corporate bankruptcy. Journal of Finance 23(4), 589-609.

Balakrishnan, K., Watts, R., Zuo, L., 2015. The effect of accounting conservatism on corporate investment during the global financial crisis. Working paper.

Ball, R., Shivakumar, L., 2005. Earnings quality in UK private firms: comparative loss recognition timeliness. Journal of Accounting and Economics 39, 83-128.

Ball, R., Robin, A., Sadka, G., 2008. Is financial reporting shaped by equity markets or by debt markets? An international study of timeliness and conservatism. Review of Accounting Studies 13, 168-205.

Basu, S., 1997. The conservatism principle and the asymmetric timeliness of earnings. Journal of Accounting and Economics 24: 3-37.

Beaver, W., Ryan, S., 2000. Biases and lags in book value and their effects on the ability of the book-to-market ratio to predict book return on equity. Journal of Accounting Research $38(1), 127-148$.

Boubakri, N., Ghouma, H., 2010. Control/ownership structure, creditor rights protection, and the cost of debt financing: international evidence. Journal of Banking and Finance 34, 24812499.

Bushman, M. R., Piotroski, J. D., Smith, A. J., 2011. Capital allocation and timely accounting recognition of economic losses. Journal of Business Finance Accounting 38(1), 1-33.

Chen, J., Chen, J., Lobo, G., Wang, Y., 2010. Association between borrower and lender state ownership and accounting conservatism. Journal of Accounting Research 48(5), 973-1014.

Chen. S, Sun, Z., Tang, S., Wu, D., 2011. Government intervention and investment efficiency: Evidence from China. Journal of Corporate Finance 17, 259-271. 
Chen, Z., Lobo, G. J., Wang, Y., Yu, L., 2013. Loan collateral and financial reporting conservatism: Chinese evidence. Journal of Banking and Finance 37, 4989-5006.

Duchin, R., Ozbas, O., Sensoy, B., 2010. Costly external finance, corporate investment, and the subprime mortgage credit crisis. Journal of Financial Economics 97, 418-435.

Firth, M., Lin, C., Wong, M.L., 2008. Leverage and investment under a state-owned bank lending environment: evidence from China. Journal of Corporate Finance 14, 642-653.

Firth, M., Lin, C., Liu, P., Wong, S. M. L., 2009. Inside the black box: Bank credit allocation in China's private sector. Journal of Banking and Finance 33, 1144-1155.

Francis, B., Hasan, I., Wu, Q., 2013. The benefits of conservative accounting to shareholders: Evidence from the financial crisis. Accounting Horizons 27(2), 319-346.

Garcia Lara, J., B. Garcia Osama, and F. Penalva, 2016. Accounting conservatism and firm investment efficiency. Journal of Accounting and Economics 61(1), 221-238.

Garcia-Appendini, E., Montoriol-Garriga, J., 2013. Firms as liquidity providers: Evidence from the 2007-2008 financial crisis. Journal of Financial Economics 109, 272-291.

Givoly, D. and C. Hayn, 2000. The changing time series properties of earnings, cash flows, and accrual: has financial reporting become more conservative? Journal of Accounting and Economics 29: 287-320.

Haw, I., Lee, J., Lee, W., 2014. Debt financing and accounting conservatism in private firms. Contemporary Accounting Research 31(4), 1220-1259.

Ivashina, V., Scharfstein, D., 2010. Bank lending during the financial crisis of 2008. Journal of Financial Economics 97, 319-338.

Khan, M. and R. L. Watts, 2009. Estimation and empirical properties of a firm-year measure of accounting conservatism. Journal Accounting and Economics 48: 132-150.

Klock, M., Mansi, S., Maxwell, W., 2005. Does corporate governance matter to bondholders? Journal of Financial and Quantitative Analysis 40(4), 693-719.

Lafond, R., Roychowdhury, S., 2008. Managerial ownership and accounting conservatism. Journal of Accounting Research 46(1), 101-135.

Lin, C., Ma, Y., Malatesta, P., Xuan, Y., 2011. Ownership structure and the cost of corporate borrowing. Journal of Financial Economics 100, 1-23.

Nikolaev, V., 2010. Debt covenants and accounting conservatism. Journal of Accounting Research 48(1), 137-176.

Watts, R. L., 2003a. Conservatism in accounting part I: Explanations and implications. Accounting Horizons 17, 207-221. 
Watts, R. L., 2003b. Conservatism in accounting part II: Evidence and research opportunities. Accounting Horizons 17, 287-301.

Xu, N., Xu, X., Yuan, Q., 2011. Political connections, financing friction, and corporate investment: Evidence from Chinese listed family firms. European Financial Management 19(4), 675-702.

Zhang, J., 2008. The contracting benefits of accounting conservatism to lenders and borrowers. Journal of Accounting and Economics 45, 27-54.

Zheng, Y., Zhu, Y., 2013. Bank lending incentives and firm investment decisions in China. Journal of Multinational Financial Management 23, 146-165. 
Table 1. Summary statistics

\begin{tabular}{lllll}
\hline & Mean & Median & $25 \%$ & $75 \%$ \\
\hline Bankloan & $23.99 \%$ & $23.09 \%$ & $10.01 \%$ & $35.33 \%$ \\
Investment & $1.70 \%$ & $0.91 \%$ & $0.27 \%$ & $2.33 \%$ \\
C_Score & 0.235 & 0.214 & 0.205 & 0.267 \\
Con_Acc & -0.010 & -0.003 & -0.022 & 0.015 \\
Con_Mar & -0.123 & -0.104 & -0.161 & -0.066 \\
Q & 1.70 & 1.31 & 1.07 & 1.86 \\
Lev & $52.38 \%$ & $52.10 \%$ & $37.40 \%$ & $65.50 \%$ \\
Asset & 21.63 & 21.52 & 20.78 & 22.36 \\
Sale & $18.43 \%$ & $14.65 \%$ & $8.50 \%$ & $23.18 \%$ \\
Tangibility & $24.41 \%$ & $22.62 \%$ & $13.82 \%$ & $35.55 \%$ \\
ROS & $4.28 \%$ & $4.92 \%$ & $1.02 \%$ & $10.83 \%$ \\
ROA & $1.55 \%$ & $1.39 \%$ & $0.23 \%$ & $3.59 \%$ \\
Cashflow & $4.89 \%$ & $4.52 \%$ & $0.86 \%$ & $11.07 \%$ \\
Board & 9.31 & 9 & 9 & 10 \\
Indep & 0.36 & 0.33 & 0.33 & 0.375 \\
LnGDP & 10.25 & 10.50 & 10.19 & 10.90 \\
Z-score & 2.33 & 2.04 & 1.37 & 2.89 \\
Wedge & $6.25 \%$ & $0.25 \%$ & 0 & $11.36 \%$ \\
\hline
\end{tabular}

This table presents the summary statistics of all the variables used in this study. These variables are defined the same as those in the Appendix. Specifically, C_Score, Con_Acc, Con_Mar, Z-score and Wedge are measured as of the third quarter of 2008, which is one quarter prior to the implementation of the stimulus package.

Table 2. Univariate tests of bank lending and firm investment

\begin{tabular}{|c|c|c|c|}
\hline & Accounting conservatism & Less & t-values \\
\hline \multicolumn{4}{|c|}{ Panel A: Full sample } \\
\hline Before & $\begin{array}{l}23.96 \% \\
(1.66 \%)\end{array}$ & $\begin{array}{l}21.87 \% \\
(1.61 \%)\end{array}$ & $\begin{array}{l}4.36 * * * \\
(2.41 * * *)\end{array}$ \\
\hline After & $\begin{array}{l}25.86 \% \\
(1.79 \%)\end{array}$ & $\begin{array}{l}24.00 \% \\
(1.72 \%)\end{array}$ & $\begin{array}{l}1.99 * * \\
(2.35 * *)\end{array}$ \\
\hline \multicolumn{3}{|c|}{ Change of the difference between Before and After } & $\begin{array}{l}2.27 * * \\
(0.23)\end{array}$ \\
\hline \multicolumn{4}{|c|}{ Panel B: SOEs } \\
\hline Before & $\begin{array}{l}24.15 \% \\
(1.75 \%)\end{array}$ & $\begin{array}{l}22.31 \% \\
(1.70 \%)\end{array}$ & $\begin{array}{l}1.55 \\
(1.13)\end{array}$ \\
\hline After & $\begin{array}{l}26.80 \% \\
(1.91 \%)\end{array}$ & $\begin{array}{l}25.28 \% \\
(1.86 \%)\end{array}$ & $\begin{array}{l}0.98 \\
(0.99)\end{array}$ \\
\hline \multicolumn{3}{|c|}{ Change of the difference between Before and After } & $\begin{array}{l}0.55 \\
(0.20)\end{array}$ \\
\hline \multicolumn{4}{|c|}{ Panel C: Non-SOEs } \\
\hline Before & $\begin{array}{l}23.68 \% \\
(1.59 \%)\end{array}$ & $\begin{array}{l}21.25 \% \\
(1.49 \%)\end{array}$ & $\begin{array}{l}4.36 * * * \\
(3.33 * * *)\end{array}$ \\
\hline After & $\begin{array}{l}24.52 \% \\
(1.66 \%)\end{array}$ & $\begin{array}{l}22.16 \% \\
(1.58 \%)\end{array}$ & $\begin{array}{l}2.35 * * \\
(1.95 *)\end{array}$ \\
\hline \multicolumn{3}{|c|}{ Change of the difference between Before and After } & $\begin{array}{l}2.88 * * * \\
(2.33 * *)\end{array}$ \\
\hline
\end{tabular}

This table reports the difference tests of bank lending and firm investment between firms with more and less conservative accounting before and after the implementation of stimulus package. The values of bank loan ratio are reported in the table and values of firm investment are reported in the brackets. *,** and *** indicate the significance levels of $10 \%, 5 \%$ and $1 \%$, respectively. 
Table 3. The effect of accounting conservatism on bank lending incentives before and after the implementation of the stimulus package

\begin{tabular}{lll}
\hline Dependent variable is total bank loan ratio & \\
\hline Stimulus & $0.037 * * *$ & $0.069^{* *}$ \\
C_Score*Stimulus & $(3.95)$ & $(4.58)$ \\
& & $-0.038^{* *}$ \\
ROS & $0.102^{* * *}$ & $(-2.27)$ \\
& $(4.15)$ & $0.099^{* * *}$ \\
Asset & $0.055^{* * *}$ & $(4.34)$ \\
& $(5.35)$ & $0.055^{* * *}$ \\
Sale & $0.115^{* * *}$ & $(5.18)$ \\
& $(21.45)$ & $0.116^{* * *}$ \\
Q & $0.004^{* * *}$ & $(21.73)$ \\
& $(6.75)$ & $0.005^{* * *}$ \\
Tangibility & $0.144 * * *$ & $(7.51)$ \\
& $(12.62)$ & $0.137 * * *$ \\
Board & -0.018 & $(12.08)$ \\
Indep & $(-0.72)$ & -0.020 \\
& -0.053 & $(-1.32)$ \\
LnGDP & $(-0.75)$ & -0.050 \\
& $0.002^{* *}$ & $(-1.51)$ \\
Constant & $(2.02)$ & $0.002^{* *}$ \\
Quarter fixed effects & $-0.855^{* * *}$ & $(2.02)$ \\
Firm fixed effects & $(-6.43)$ & $-0.836^{* * *}$ \\
Adjusted R & Included & $(-6.32)$ \\
Observations & Included & Included \\
\hline This table reports the & 0.14 & Included \\
& 62700 & 0.15 \\
& 62700 \\
\hline
\end{tabular}

This table reports the results of the effect of accounting conservatism on bank lending incentives before and after the implementation of the stimulus package. Definitions of all variables are the same as in Appendix. Tvalues are reported in brackets, $* *$ and $* * *$ indicate the significance levels of $5 \%$ and $1 \%$, respectively. 
Table 4. The effect of accounting conservatism on firm investment efficiency before and after the implementation of the stimulus package

\begin{tabular}{llll}
\hline Dependent variable is investment expenditure & & $0.029^{* *}$ \\
\hline C_Score*Q & & $0.014^{* *}$ & $(2.55)$ \\
& & $(2.29)$ & $-0.038^{* * *}$ \\
C_Score*Q*Stimulus & & $(-3.06)$ \\
& & -0.167 \\
C_Score*Stimulus & & $-1.51)$ \\
Q*Stimulus & & $-0.019^{* *}$ \\
& & & $(-2.06)$ \\
Stimulus & $0.004^{* * *}$ & & $0.009^{* * *}$ \\
& $(5.31)$ & $0.004^{* * *}$ & $(7.01)$ \\
Q & $0.004^{* * *}$ & $(5.26)$ & $0.012^{* * *}$ \\
& $(2.90)$ & $0.007^{* * *}$ & $(2.92)$ \\
Lev & $-0.065^{* * *}$ & $(2.66)$ & $-0.059^{* * *}$ \\
& $(-9.18)$ & $-0.064^{* * *}$ & $(-8.31)$ \\
Asset & $0.015^{* * *}$ & $(-9.14)$ & $0.016^{* * *}$ \\
& $(7.98)$ & $0.015^{* * *}$ & $(8.25)$ \\
Sale & $0.066^{* *}$ & $(7.78)$ & $0.066^{* *}$ \\
& $(5.44)$ & $0.065^{* *}$ & $(5.52)$ \\
Tangibility & $0.102^{* * *}$ & $(5.43)$ & $0.108^{* * *}$ \\
& $(4.08)$ & $0.101^{* * *}$ & $(4.32)$ \\
Cashflow & $0.569^{* * *}$ & $(4.06)$ & $0.569^{* * *}$ \\
& $(11.31)$ & $0.568^{* * *}$ & $(1.31)$ \\
Board & 0.004 & $(11.29)$ & 0.004 \\
& $(1.15)$ & 0.004 & $(1.07)$ \\
Indep & 0.002 & $(1.14)$ & 0.002 \\
& $(0.63)$ & 0.002 & $(0.65)$ \\
LnGDP & $0.009^{* * *}$ & $(0.63)$ & $0.009^{* * *}$ \\
& $(4.40)$ & $0.009^{* * *}$ & $(4.42)$ \\
Constant & $1.004^{* * *}$ & $(4.40)$ & $0.984^{* * *}$ \\
& $(3.42)$ & $1.008^{* * *}$ & $(3.36)$ \\
Quarter fixed effects & Included & $(3.44)$ & Included \\
Firm fixed effects & Included & Included & Included \\
Adjusted R & Included & 0.19 \\
Observations & 0.16 & 0.17 & 62700 \\
\hline
\end{tabular}

This table reports the results of the effect of accounting conservatism on firm investment efficiency before and after the implementation of the stimulus package. Definitions of all variables are the same as in Appendix. Tvalues are reported in brackets, ** and $* * *$ indicate the significance levels of $5 \%$ and $1 \%$, respectively. 
Table 5. The dynamic effects of the influence of the implementation of the stimulus package

\begin{tabular}{|c|c|c|}
\hline & Bank lending incentive regression & Firm investment efficiency regression \\
\hline \multirow{2}{*}{ Before $_{t-1}$} & 0.018 & 0.004 \\
\hline & $(1.46)$ & $(1.63)$ \\
\hline \multirow[t]{2}{*}{ Current } & $0.043 *$ & $0.004 * * *$ \\
\hline & $(1.90)$ & $(3.80)$ \\
\hline \multirow{2}{*}{ After $_{t+1}$} & $0.062 * *$ & $0.015 * * *$ \\
\hline & $(2.03)$ & $(3.59)$ \\
\hline \multirow[t]{2}{*}{ After $_{t+2}$} & $0.093 * * *$ & $0.016 * * *$ \\
\hline & $(9.74)$ & $(6.10)$ \\
\hline C_Score*Before ${ }_{\mathrm{t}-1}$ & $\begin{array}{l}-0.168 \\
(-0.96)\end{array}$ & \\
\hline C_Score*Current & $\begin{array}{l}-0.205^{* * *} \\
(-3.42)\end{array}$ & \\
\hline C_Score* After ${ }_{t+1}$ & $\begin{array}{l}-0.239 * * * \\
(-4.04)\end{array}$ & \\
\hline C_Score ${ }^{*}$ After ${ }_{t+2}$ & $\begin{array}{l}-0.420 * * * \\
(-3.24)\end{array}$ & \\
\hline C_Score ${ }^{*} \mathrm{Q}^{*}$ Before $_{\mathrm{t}-1}$ & & $\begin{array}{l}0.041 \\
(1.50)\end{array}$ \\
\hline C_Score* $\mathrm{Q}^{*}$ Current & & $\begin{array}{l}-0.048 * \\
(-1.92)\end{array}$ \\
\hline C_Score*Q*After ${ }_{t+1}$ & & $\begin{array}{l}-0.022^{*} \\
(-1.91)\end{array}$ \\
\hline C_Score ${ }^{*} \mathrm{Q}^{*}$ After $_{\mathrm{t}+2}$ & & $\begin{array}{l}-0.045 * * * \\
(-5.52)\end{array}$ \\
\hline \multicolumn{3}{|c|}{ Control variables and other interaction terms from equations (1) and (2) are also included in each regression } \\
\hline Adjusted $\mathrm{R}^{2}$ & 0.12 & 0.15 \\
\hline Observations & 62700 & 62700 \\
\hline
\end{tabular}

This table reports the results of the dynamic effects of the implementation of the stimulus package on the relationship between accounting conservatism and bank lending incentives and firm investment efficiency. Before $_{\mathrm{t}-1}$ is a dummy variable equal to 1 for observations one quarter preceding the implementation of the stimulus package. Current is a dummy variable equal to 1 for observations in the quarter when the stimulus package is implemented. After $r_{t+1}$ is a dummy variable equal to 1 for observations one quarter after the implementation of the stimulus package. After $\mathrm{t}_{\mathrm{t}+2}$ is a dummy variable equal to 1 for observations two quarters or more after the implementation of the stimulus package. Definitions of all variables are the same as in Appendix. T-values are reported in brackets, *,** and *** indicate the significance levels of $10 \%, 5 \%$ and $1 \%$, respectively. 
Table 6. The influence of accounting conservatism: SOEs vs. non-SOEs

\begin{tabular}{lcl}
\hline & SOEs & Non-SOEs \\
\hline \multicolumn{2}{l}{ Panel A: Bank lending incentive regression } & \\
\hline Stimulus & $0.042^{* *}$ & $0.138^{* * *}$ \\
& $(2.20)$ & $(6.58)$ \\
C_Score*Stimulus & $-0.024^{* *}$ & $-0.073^{* * *}$ \\
& $(-1.97)$ & $(-2.93)$ \\
Control variables from equation (1) are also included & \\
Chow tests & $5.66^{* *}$ & \\
Adjusted R & 0.14 & 0.15 \\
Observations & 36833 & 25867 \\
\hline Panel B: Firm investment efficiency regression & \\
\hline C_Score*Q & 0.069 & $0.023 * *$ \\
& $(1.02)$ & $(2.15)$ \\
C_Score*Q*Stimulus & -0.018 & $-0.056^{* * *}$ \\
& $(-0.60)$ & $(-2.78)$ \\
Control variables and other interaction terms from equation $(2)$ are also included \\
Chow tests & $7.33 * * *$ & \\
Adjusted $\mathrm{R}^{2}$ & 0.13 & 0.17 \\
Observations & 36833 & 25867 \\
\hline
\end{tabular}

This table reports the results of the effect of accounting conservatism on bank lending incentives and firm investment efficiency before and after the implementation of the stimulus package for both SOEs and non-SOEs. Definitions of all variables are the same as in Appendix. Chow tests report the significance of difference of the interaction terms with Stimulus between SOEs and non-SOEs. T-values are reported in brackets, ** and *** indicate the significance levels of $5 \%$ and $1 \%$, respectively.

Table 7. The influence of accounting conservatism: more favoured vs. less favoured industries

\begin{tabular}{|c|c|c|}
\hline & More favoured industries & Less favoured industries \\
\hline \multicolumn{3}{|c|}{ Panel A: Bank lending incentive regression } \\
\hline \multirow[t]{2}{*}{ Stimulus } & $0.022 * * *$ & $0.109 * * *$ \\
\hline & $(2.60)$ & $(8.41)$ \\
\hline \multirow[t]{2}{*}{ C_Score*Stimulus } & $-0.029 *$ & $-0.095 * * *$ \\
\hline & $(-1.92)$ & $(-8.71)$ \\
\hline \multicolumn{3}{|c|}{ Control variables from equation (1) are also included } \\
\hline Chow tests & $9.13 * * *$ & \\
\hline Adjusted $\mathrm{R}^{2}$ & 0.19 & 0.28 \\
\hline Observations & 20914 & 41786 \\
\hline \multicolumn{3}{|c|}{ Panel B: Firm investment efficiency regression } \\
\hline \multirow[t]{2}{*}{ C_Score*Q } & 0.095 & $0.014 * * *$ \\
\hline & $(1.25)$ & $(2.69)$ \\
\hline \multirow[t]{2}{*}{ C_Score $* Q^{*}$ Stimulus } & -0.014 & $-0.041 * * *$ \\
\hline & $(-1.49)$ & $(-3.35)$ \\
\hline \multicolumn{3}{|c|}{ Control variables and other interaction terms from equation (2) are also included } \\
\hline Chow tests & $6.12 * *$ & \\
\hline Adjusted $\mathrm{R}^{2}$ & 0.14 & 0.15 \\
\hline Observations & 20914 & 41786 \\
\hline
\end{tabular}

This table reports the results of the effect of accounting conservatism on bank lending incentives and firm investment efficiency before and after the implementation of the stimulus package for firms from both more favoured and less favoured industries. Definitions of all variables are the same as in Appendix. Chow tests report the significance of difference of the interaction terms with Stimulus between firms from more favoured and less favoured industries. T-values are reported in brackets, *** and *** indicate the significance levels of $10 \%, 5 \%$ and $1 \%$, respectively. 
Table 8. The influence of accounting conservatism: more favoured vs. less favoured regions

\begin{tabular}{lcl}
\hline & More favoured regions & \multicolumn{1}{c}{ Less favoured regions } \\
\hline \multicolumn{2}{l}{ Panel A: Bank lending incentive regression } & \\
\hline Stimulus & $0.053^{*}$ & $0.083^{* * *}$ \\
& $(1.90)$ & $(6.43)$ \\
C_Score*Stimulus & -0.030 & $-0.046^{* * *}$ \\
& $(-1.43)$ & $(-3.59)$ \\
Control variables from equation (1) are also included & \\
Chow tests & $8.56^{* * *}$ & \\
Adjusted R & 0.14 & 0.12 \\
Observations & 31664 & 31036 \\
\hline Panel B: Firm investment efficiency regression & \\
\hline C_Score*Q & $0.016^{* *}$ & $0.058^{* * *}$ \\
& $(2.16)$ & $(3.07)$ \\
C_Score*Q*Stimulus & -0.012 & $-0.064 * *$ \\
& $(-1.35)$ & $(-2.37)$ \\
Control variables and other interaction terms from equation $(2)$ are also included \\
Chow tests & $4.45^{* *}$ & \\
Adjusted $\mathrm{R}^{2}$ & 0.17 & 0.12 \\
Observations & 31664 & 31036 \\
\hline
\end{tabular}

This table reports the results of the effect of accounting conservatism on bank lending incentives and firm investment efficiency before and after the implementation of the stimulus package for firms from both more favoured and less favoured regions. Definitions of all variables are the same as in Appendix. Chow tests report the significance of difference of the interaction terms with Stimulus between firms from more favoured and less favoured regions. T-values are reported in brackets, $* * *$ and $* * *$ indicate the significance levels of $10 \%, 5 \%$ and $1 \%$, respectively.

Table 9. The influence of accounting conservatism: more financial distress vs. less financial distress

\begin{tabular}{lcc}
\hline & More financial distress & Less financial distress \\
\hline Panel A: Bank lending incentive regression & \\
\hline Stimulus & $0.120^{* * *}$ & $0.015^{* *}$ \\
& $(3.95)$ & $(2.26)$ \\
C_Score*Stimulus & $-0.062^{* * *}$ & -0.013 \\
& $(-2.78)$ & $(-1.15)$ \\
Control variables from equation (1) are also included & \\
Chow tests & $5.92^{* *}$ & \\
Adjusted R & 0.16 & 0.13 \\
Observations & 30723 & 31977 \\
\hline Panel B: Firm investment efficiency regression & \\
\hline C_Score*Q & $0.046^{* *}$ & $0.017 *$ \\
& $(2.30)$ & $(1.92)$ \\
C_Score*Q*Stimulus & $-0.040^{* *}$ & -0.016 \\
& $(-2.28)$ & $(-0.23)$ \\
Control variables and other interaction terms from equation $(2)$ are also included \\
Chow tests & $5.89 * *$ & \\
Adjusted R & 0.18 & 0.15 \\
Observations & 30723 & 31977 \\
\hline
\end{tabular}

This table reports the results of the effect of accounting conservatism on bank lending incentives and firm investment efficiency before and after the implementation of the stimulus package for both firms with more financial distress and less financial distress. Definitions of all variables are the same as in Appendix. Chow tests report the significance of difference of the interaction terms with Stimulus between firms with more financial distress and less financial distress. T-values are reported in brackets, $* *$ and $* * *$ indicate the significance levels of $5 \%$ and $1 \%$, respectively. 
Table 10. The influence of accounting conservatism: with control-ownership wedge vs. without controlownership wedge

\begin{tabular}{lcc}
\hline & With control-ownership wedge & Without control-ownership wedge \\
\hline \multicolumn{2}{l}{ Panel A: Bank lending incentive regression } & \\
\hline Stimulus & $0.086^{* * *}$ & $0.042^{* * *}$ \\
& $(6.69)$ & $(2.68)$ \\
C_Score*Stimulus & $-0.040^{* * *}$ & -0.029 \\
& $(-4.00)$ & $(-1.17)$ \\
Control variables from equation (1) are also included & \\
Chow tests & $6.23^{* *}$ & \\
Adjusted R & 0.13 & 0.15 \\
Observations & 32353 & 30347 \\
\hline Panel B: Firm investment efficiency regression & \\
\hline C_Score*Q & $-0.038^{* * *}$ & -0.017 \\
& $(-2.86)$ & $(-1.32)$ \\
C_Score*Q*Stimulus & $-0.050^{* * *}$ & 0.007 \\
& $(-3.17)$ & $(0.27)$ \\
Control variables and other interaction terms from equation $(2)$ are also included \\
Chow tests & $7.00^{* * *}$ & \\
Adjusted R & 0.13 & 0.13 \\
Observations & 32353 & 30347 \\
\hline
\end{tabular}

This table reports the results of the effect of accounting conservatism on bank lending incentives and firm investment efficiency before and after the implementation of the stimulus package for both firms with and without control-ownership wedge. Definitions of all variables are the same as in Appendix. Chow tests report the significance of difference of the interaction terms with Stimulus between firms with and without controlownership wedge. T-values are reported in brackets, $* *$ and $* * *$ indicate the significance levels of $5 \%$ and $1 \%$, respectively.

Table 11. The effect of accounting conservatism on future profitability

\begin{tabular}{lll}
\hline Dependent variable & Cashflow & \multicolumn{1}{c}{ ROA } \\
\hline Stimulus & $0.012^{* * *}$ & $0.006^{* * *}$ \\
& $(4.27)$ & $(8.19)$ \\
C_Score*Stimulus & $-0.014^{* *}$ & $-0.049^{* * *}$ \\
& $(-2.05)$ & $(-4.14)$ \\
Asset & $-0.018^{* * *}$ & $-0.004^{* * *}$ \\
& $(-30.46)$ & $(-21.58)$ \\
Lev & $0.018^{* * *}$ & $-0.003^{* * *}$ \\
& $(7.55)$ & $(-5.05)$ \\
Sale & $0.365^{* * *}$ & $0.019^{* * *}$ \\
& $(8.11)$ & $(18.32)$ \\
Board & -0.01 & -0.001 \\
& $(-0.30)$ & $(-0.21)$ \\
Indep & $0.017^{* *}$ & $0.006^{* * *}$ \\
& $(1.96)$ & $(2.88)$ \\
Constant & $0.506^{* * *}$ & $0.082^{* * *}$ \\
& $(33.98)$ & $(20.53)$ \\
Quarter fixed effects & Included & Included \\
Firm fixed effects & Included & Included \\
Adjusted $\mathrm{R}^{2}$ & 0.15 & 0.08 \\
Observations & 59778 & 59778 \\
\hline
\end{tabular}

This table reports the results of the effect of accounting conservatism on firm performance before and after the implementation of the stimulus package. Definitions of all variables are the same as in Appendix. T-values are reported in brackets, ** and *** indicate the significance levels of $5 \%$ and $1 \%$, respectively. 


\begin{tabular}{|c|c|}
\hline Variables & Definitions \\
\hline C_Score & $\begin{array}{l}\text { The proxy for accounting conservatism, measured in the third quarter of } 2008 \\
\text { which is one quarter prior to the implementation of the stimulus package. Detailed } \\
\text { calculation is listed in section } 3.2 \text {. }\end{array}$ \\
\hline Stimulus & $\begin{array}{l}\text { Equals } 1 \text { for firm-quarter observations falling in the post-stimulus period, and } 0 \text { for } \\
\text { the pre-stimulus period. In particular, pre-stimulus period covers } 2003 \text { to the third } \\
\text { quarter of } 2008 \text {, and post-stimulus period covers the fourth quarter of } 2008 \text { to } \\
2014 \text {. }\end{array}$ \\
\hline Bankloan & The ratio of firm total bank loans to total assets in current quarter \\
\hline Investment & Capital expenditure/Total assets in the current quarter \\
\hline ROS & Net income/Sales in the current quarter \\
\hline ROA & Net income/Total assets in the current quarter \\
\hline Asset & Natural log of total assets in the current quarter \\
\hline Sale & Net sales/Total assets in the current quarter \\
\hline Tangibility & Tangible assets/Total assets in the current quarter \\
\hline Q & Market value/Replacement value in the current quarter \\
\hline Leverage (Lev) & Total debt/Total assets in the current quarter \\
\hline Cashflow & (Net income + depreciation)/Total sales in the current quarter \\
\hline Board & Number of total directors on the boards in the current quarter \\
\hline Indep & $\begin{array}{l}\text { Number of independent directors/Total number of directors on board in the current } \\
\text { quarter }\end{array}$ \\
\hline LnGDP & Natural log of GDP per capita in each province \\
\hline Z_score & $\begin{array}{l}\text { The Z-score developed by Altman }(1968) \text {. In particular, Z-score }=0.012 \mathrm{X}_{1}+ \\
0.014 \mathrm{X}_{2}+0.033 \mathrm{X}_{3}+0.006 \mathrm{X}_{4}+0.999 \mathrm{X}_{5} \text {, where } \mathrm{X}_{1}=\text { working capital/Total assets, } \\
\mathrm{X}_{2}=\text { retained earnings/Total assets, } \mathrm{X}_{3}=\text { Earnings before interest and taxes/Total } \\
\text { assets, } \mathrm{X}_{4}=\text { Market value of equity/Book value of total debt, and } \mathrm{X}_{5}=\text { Sales/Total } \\
\text { assets. The value of this variable is measured in the third quarter of } 2008 \text {. }\end{array}$ \\
\hline Wedge & $\begin{array}{l}\text { Difference between the control rights and cash flow rights of the controlling } \\
\text { shareholders. The value of this variable is measured in the third quarter of } 2008 \text {. }\end{array}$ \\
\hline
\end{tabular}

